\title{
Immunomodulating Effect of Neurotropin on Delayed Type Hypersensitivity Response in Mice
}

\author{
Haruo YOSHII, Takao MATSUOKA, Yoshiyuki KURIMOTO \\ and Seishi SUEHIRO \\ Department of Immunology and Allergy, Institute of Bio-Active Science. \\ Nippon Zoki Pharmaceutical Company. Hyogo 673-14. Japan
}

Accepted May 26, 1988

\begin{abstract}
Effect of Neurotropin on the delayed type hypersensitivity (DTH) response to sheep red blood cells was examined in mice. Neurotropin suppressed the high DTH responses in $d d Y$ and BALB/c mice, while it enhanced the low DTH response in $\mathrm{C} 57 \mathrm{BL} / 6$ mice when administered after sensitization. In addition, Neurotropin exerted a suppressive effect on the enhanced DTH response by cyclophosphamide pretreatment in $\mathrm{C} 57 \mathrm{BL} / 6$ mice, but had a restorative effect on the suppressed DTH response in ddY mice loaded with restraint stress.
\end{abstract}

In a previous report (1). we have demonstrated that Neurotropin enhanced the DTH response to sheep red blood cells (SRBC) in low responder $\mathrm{C} 57 \mathrm{BL} / 6$ mice through the induction of Lyt $1^{+} 2^{-}$DTH helper T cells. To clarify the immunopharmacological action of Neurotropin more precisely, its effect on the DTH response was examined further.

Outbred ddY, inbred BALB/C and C57BL/6 male mice were purchased from Shizuoka Laboratory Animal Center. Shizuoka, Japan. Mice of 7-10 weeks of age were used for all experiments. Neurotropin, a non-proteinaceous and standardized extract containing biologically active principle(s) isolated from the inflamed dermis of rabbits inoculated with vaccinia virus, has been safely and widely used as an analgesic and antiallergic drug in Japan (2). The concentrated form of commercially available Neurotropin (10 mg dry weight/ml; Nippon Zoki Pharmaceutical Co.. Osaka, Japan) was diluted with saline and administered at 10,20 and $50 \mathrm{mg} / \mathrm{kg} / \mathrm{day}$. Cyclophosphamide (CP) was purchased from Nakarai Chemical Co., Ltd., Kyoto, Japan. SRBC were obtained from Nippon Bio-supp. Center, Tokyo, Japan. In stress loading experiments, ddY mice were confined in restraint cages $(25 \mathrm{~mm}$ diameter, $90 \mathrm{~mm}$ length, made of steel wire net) from 5:00 PM to 9:00 AM for 2 consecutive days. DTH responses to $S R B C$ were measured as follows: Mice were sensitized with $1 \times 10^{7} \mathrm{SRBC}$ in the left footpad and were challenged with $1 \times 10^{8}$ SRBC 4 days after sensitization in the right footpad. The degree of swelling compared to the uninjected footpad was measured with a dial thickness gauge at $24 \mathrm{hr}$ after the challenge.

Whether Neurotropin would modulate different levels of DTH response in ddY. BALB/c and $\mathrm{C} 57 \mathrm{BL} / 6$ mice when administered after sensitization was examined. As shown in Fig. 1. $10-50 \mathrm{mg} / \mathrm{kg} /$ day Neurotropin tended to suppress the high DTH response in ddY when administered p.o. for 4 consecutive days. Neurotropin had the same effect with a peak suppression at $20 \mathrm{mg} / \mathrm{kg} /$ day in the ddY mice even if administered i.p. for 4 consecutive days after sensitization (data not shown). Similarly. $10-50 \mathrm{mg} / \mathrm{kg} /$ day Neurotropin dose-dependently suppressed the high DTH response in BALB/c mice in the i.p. route. Conversely. $10-50 \mathrm{mg} / \mathrm{kg} /$ day Neurotropin clearly enhanced the low DTH response in $\mathrm{C} 57 \mathrm{BL} / 6$ mice. with a peak enhancement at $20 \mathrm{mg} / \mathrm{kg} /$ day. These results indicate that Neurotropin administered after sensitization exerts suppressive effects on the high DTH responses. but has an enhancing effect on the low response in mice. However, the possibility exists that Neurotropin may have modulating 
actions on DTH response only in intact mice of particular strains. In order to explore this possibility further, whether Neurotropin would modulate the experimentally altered DTH response by CP pretreatment or restraint stress loading was investigated. As shown in Table 1. Neurotropin tended to suppress the
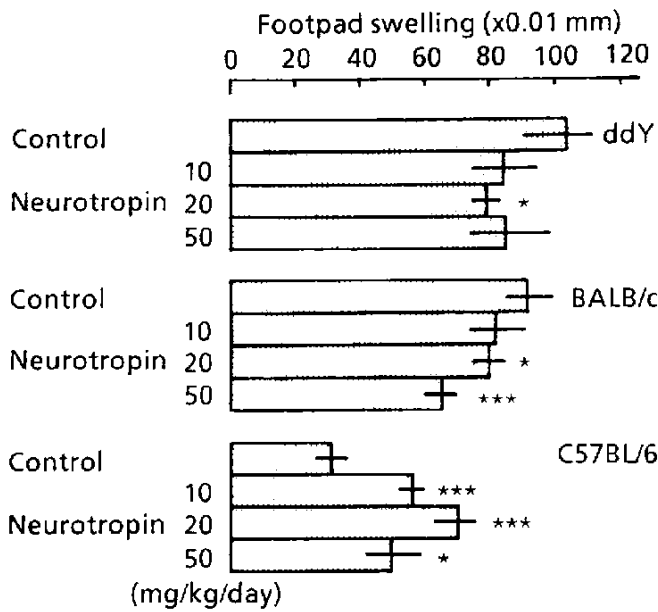

C57BL/6

Fig. 1. Effect of Neurotropin on DTH response to $S R B C$ in three strains of mice. ddY, BALB/C and C57BL/6 mice were sensitized with $1 \times 10^{7} \mathrm{SRBC}$ on day $O$ and challenged with $1 \times 10^{8}$ SRBC on day 4. Neurotropin or saline was administered p.o. into dd $Y$ mice or i.p. into BALB/C and C57BL/6 from day 0 to day 3 . Each column represents the mean \pm S.E. of 6-10 mice. ": P<0.05, ${ }^{* *}: P<0.001$ as compared to the control by Student's $t$-test.
CP-induced enhancement of DTH response in $\mathrm{C} 57 \mathrm{BL} / 6$ mice in a dose-dependent manner, whereas it clearly enhanced the low DTH response in intact $\mathrm{C} 57 \mathrm{BL} / 6$ mice, with a peak enhancement at $20 \mathrm{mg} / \mathrm{kg} /$ day. On the other hand. $10-20 \mathrm{mg} / \mathrm{kg} /$ day Neurotropin exerted a restorative effect on the stressinduced suppression of DTH response, while it had a suppressive effect on the high DTH response in intact ddY mice as demonstrated in Fig. 1. These results indicate that Neurotropin can modulate not only the different levels of DTH responses of genetically predetermined nature but also the experimentally modified DTH response in mice.

Although the data were not presented, the administration of Neurotropin at any dose on the last two days of the 4 consecutive days administration had no modulating effects on the DTH responses. Furthermore, Koda et al. (2) and our group (3) have already shown that Neurotropin exerted no effect on the effector phase of DTH responses such as picryl chloride-induced contact dermatitis and cell transfer-induced local graft-versushost reaction in mice. Therefore, Neurotropin seems to have a modulating effect on the induction phase, but not on the inflammatory process in the effector phase of the DTH responses.

Neurotropin suppressed the high DTH responses in intact $d d Y$ and $B A L B / C$ mice as well as the enhanced DTH response by $C P$

Table 1. Modulating effect of Neurotropin on experimentally altered DTH response to SRBC in C57BL/ 6 and $d d Y$ mice

\begin{tabular}{|c|c|c|c|c|}
\hline \multirow{2}{*}{$\begin{array}{l}\text { Group } \\
(\mathrm{mg} / \mathrm{kg} / \mathrm{day})\end{array}$} & \multicolumn{2}{|c|}{$\mathrm{C} 57 \mathrm{BL} / 6$ mice } & \multicolumn{2}{|c|}{$d d Y$ mice } \\
\hline & Intact & CP-treated & Intact & Stressed \\
\hline Control (saline) & $36.1 \pm 2.6$ & $64.0 \pm 4.3 t \dagger t$ & $99.0 \pm 6.8$ & $74.4 \pm 8.1 \dagger$ \\
\hline Neurotropin 10 & $52.9 \pm 5.0^{* *}$ & $56.0 \pm 5.7$ & $85.5 \pm 6.9$ & $96.4 \pm 5.2^{*}$ \\
\hline 20 & $59.3 \pm 5.1^{* *}$ & $52.2 \pm 4.3$ & $73.0 \pm 5.4^{* *}$ & $106.8 \pm 7.1^{* *}$ \\
\hline 50 & $56.4 \pm 5.7^{* *}$ & $51.4 \pm 4.2^{*}$ & $77.5 \pm 6.4^{*}$ & $81.7 \pm 6.1$ \\
\hline
\end{tabular}

C57BL/6 mice (20-25 mice per group) were injected i.p. with $200 \mathrm{mg} / \mathrm{kg} \mathrm{CP}$ on day -4 . The CP-treated mice and intact mice were administered i.p. with Neurotropin or saline from day -4 to day -1 , In another experiment, ddY mice (10 mice per group) were restrained for $16 \mathrm{hr}$ per day for 2 days (day -1 and day 0 ). The restrained mice and intact mice were administered p.o. with Neurotropin or saline from day 0 to day 3 . All mice were sensitized with $1 \times 10^{7}$ SRBC on day 0 and challenged with $1 \times 10^{8}$ SRBC on day 4 . Each value (footpad swelling, $\times 0.01 \mathrm{~mm}$ ) represents the mean $\pm S$.E. T: $P<0.05$, $\uparrow \uparrow: P<0.001$, as compared to the intact control, *: P<0.05, **:P<0.01, ***:P<0.001, as compared to the corresponding control by Student's $t$-test. 
administration in $\mathrm{C} 57 \mathrm{BL} / 6$ mice. It has been demonstrated that CP pretreatment damaged the precursor for suppressor $T$ cells (Ts) involved in the DTH response, resulting in enhancement of the DTH response in mice (4. 5). Neurotropin has been reported to restore the Ts activity in aged NZB/NZW $F_{1}$ female mice (6). Therefore, it is suggested that Neurotropin suppresses these DTH responses via the augmentation of Ts activity. On the other hand. Neurotropin enhanced the low DTH responses in intact $\mathrm{C} 57 \mathrm{BL} / 6$ mice or in ddY mice loaded with the stress when administered after sensitization. Okimura et al. (7) and Komori et al. (8) have reported that restraint stress caused suppression of immune responses in mice through the depression of helper $T$ cell (Th) activity. We have already demonstrated that pretreatment with Neurotropin induced Th involved in DTH response in low responder $\mathrm{C} 57 \mathrm{BL} / 6$ mice (1). Inagaki et al. (9) have also reported that Neurotropin administration restored the decreased number of OKT $4^{+} \mathrm{T}$ lymphocytes in a hemophilia patient with acquired immune deficiency syndrome-related complex. Therefore. Neurotropin administered after sensitization may enhance the low DTH response via the augmentation of Th activity. From all of these findings, it is suggested that Neurotropin may directly or indirectly modulate the levels of DTH response through the regulation of number and/or activity of immunoregulatory $T$ cells such as $T h$ and $T s$. Further studies will be necessary to examine the mechanism by which Neurotropin modulates the DTH response at cellular levels.

\section{References}

1 Yoshii, H., Suehiro, S., Watanabe, K. and Yanagihara, $Y$.: Immunopharmacological actions of an extract isolated from inflamed skin of rabbits inoculated with vaccinia virus (Neurotropin):
Enhancing effect on delayed type hypersensitivity response through the induction of Lyt-1*2- T cells. Int. J. Immunopharmacol. 9, 443-451 (1987)

2 Koda, A., Nagai, H., Kurimoto, Y., Yamada, T., Mori, H., Nishiyori, T. and Inagaki, N.: Effect of Neurotropin (NSP) on ailergic reactions. Folia Pharmacol. Japon. 78, 319-334 (1981) (Abs. in English)

3 Yanagihara, Y., Shida, T. and Yoshii, H.: Immunopharmacological actions of Neurotropin (2): Effect of Neurotropin on graft-versus-host reaction. Folia Pharmacol. Japon. 78, 451-458 (1981) (Abs. in English)

4 Gill, H.K. and Liew, F.Y.: Regulation of delayedtype hypersensitivity III. Effect of cyclophosphamide on the suppressor cells for delayed-type hypersensitivity to sheep erythrocytes in mice. Eur. J. Immunol. 8, 172-176 (1979)

5 Mitsuoka, A., Morikawa, S., Baba, M. and Harada, T.: Cyclophosphamide eliminates suppressor $T$ cells in age-associated central regulation of delayed type hypersensitivity in mice. J. Exp. Med. 149, 1018-1028 (1979)

6 Naiki, M., Imai, Y., Nakanishi, A., Hishinuma, A. and Osawa, T.: Effect on autoimmunity developed in (NZB/NZW) $F_{1}$ mice of substance(s) extracted from inflammatory dermis of rabbits induced by inoculation of vaccinia virus. Clin. Immunol. 16, 506-516 (1984)

7 Okimura, T., Satomi-Sakaki, Y. and Ohkuma, S.: Stress and immune response $\|$. Identification of stress-sensitive cells in murine spleen cells. Japan. J. Pharmacol. 40,513-525 (1986)

8 Komori, T., Nakano, T. and Ohsugi, Y.: Alleviation of depressed immunity caused by restraintstress by the immunomodulator, lobenzarit disodium (disodium 4-chloro-2, $2^{\prime}$-iminodibenzoate). Int. J. Immunopharmacol. 9, 433-442 (1987)

9 Inagaki, M., Taki, M., Miura, T., Saitoh, N. and Yamada, K.: Effect of Neurotropin on helper lymphocyte proliferation in hemophiliacs with immune deficiency. Proc. 5th int. Symp. on Hemophilia Treatment, p. 303-309. Kyoritsu Printings. Tokyo (1986) 